\title{
Respiratory distress in neonate due to congenital nasal pyriform aperture stenosis
}

\author{
Narongsak Nakwan, ${ }^{1}$ Apiradee Songjamrat, ${ }^{2}$ Rajitkorn Phoophitphong, ${ }^{3}$ Chutima Smathakanee ${ }^{1}$ \\ ${ }^{1}$ Department of Pediatrics, Hat Yai Medical Education center, Hat yai Hospital, Hat Yai, Songkhla, Thailand \\ ${ }^{2}$ Department of Radiology, Hat Yai Medical Education center, Hat yai Hospital, Hat Yai, Songkhla, Thailand \\ ${ }^{3}$ Department of Otorhinolaryngology, Hat Yai Medical Education center, Hat yai Hospital, Hat Yai, Songkhla, Thailand
}

Correspondence to Narongsak Nakwan, nnakwan@hotmail.com

\section{DESCRIPTION}

A full-term male neonate was born by vaginal delivery developed respiratory distress, noisy breathing and central cyanosis shortly after birth. He required intubation with a low setting of conventional ventilation, and his respiratory status dramatically improved. A 5 French catheter was passed nasally with difficulty bilaterally. CT scans of the nasal cavity revealed a marked narrowing of the anterior nasal passage, which was compatible with congenital nasal pyriform aperture stenosis (CNPAS) (figure 1). At $24 \mathrm{~h}$ later, he was extubated and placed on an artificial oral airway, and his respiratory status normalised without the need for oxygen treatment. Thyroid function tests, cortisol level and cranial ultrasonography were within normal limits. He initially started on orogastric $(O G)$ tube feeding with infant formula.
On a follow-up at 2 months of age, an artificial oral airway was removed without consequently abnormal respiratory status. He had successfully transitioned from OG-tube feeding to exclusive breast feeding.

CNPAS is a rare anatomic cause of neonatal nasal obstruction and can lead to respiratory distress, noisy breathing, apnea, as well as poor feeding. ${ }^{1-3}$ CNPAS results from a bony overgrowth of the medial process of the maxillary sinus, and it could be associated with congenital anomalies such as holoprosencephaly, endocrine defects or a single maxillary central incisor. ${ }^{2}$ The management of CNPAS is dependent on the severity of the nasal obstruction. A mild case, who can take a 5 French catheter through the nasal passage, should initially be treated conservatively with local saline, steroid or stenting into nasal canals, and airway difficulties may spontaneously resolve within the first several

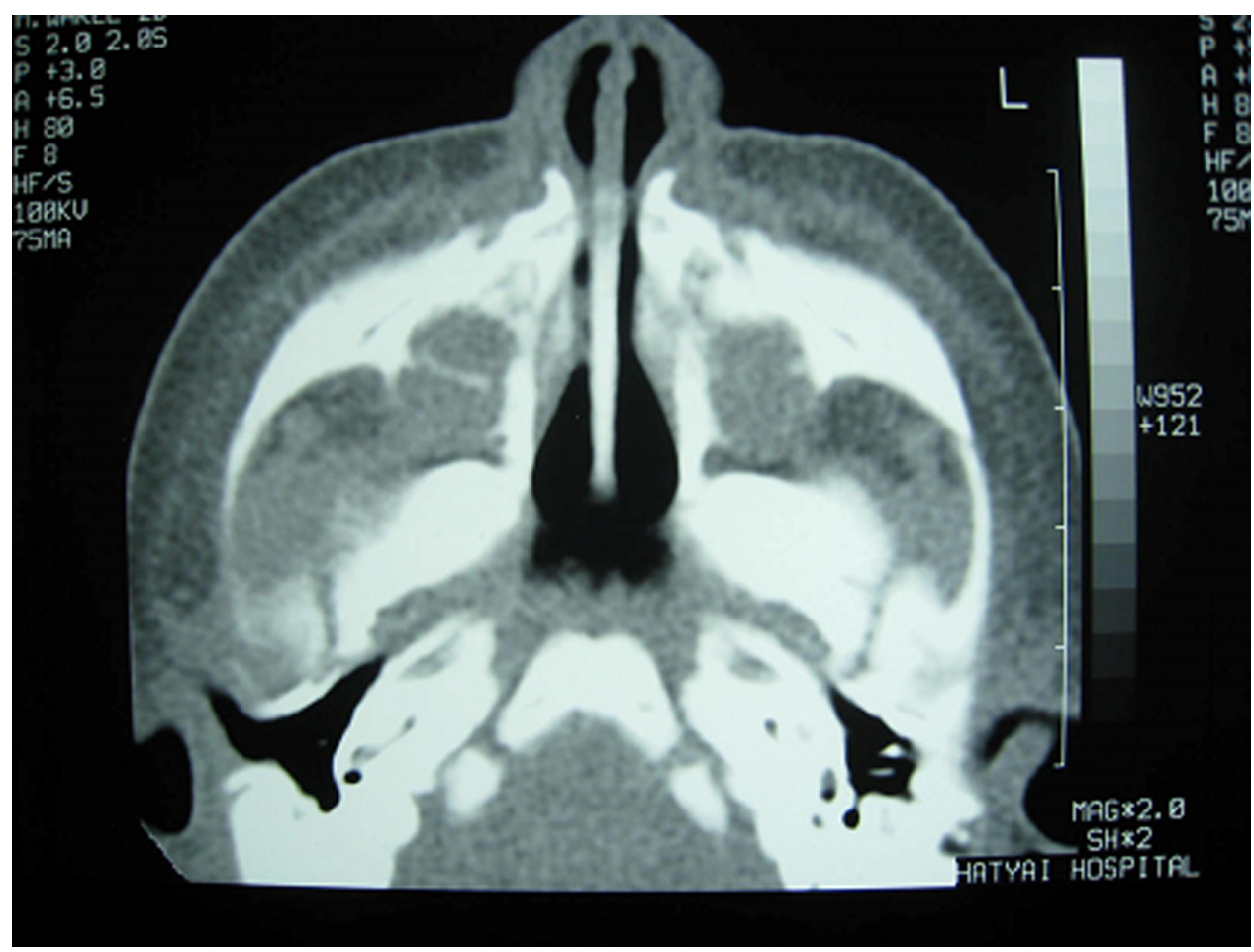

Figure 1 The CT of nasal cavity shows a marked narrowing of anterior nasal passage with an overgrowth of the medial nasal process of maxilla. 


\section{BMJ Case Reports}

months of life $e^{1-3}$ Hui et al ${ }^{2}$ suggested that the failure to pass a 5 French catheter through the nasal airway is a severe case and is an indication for surgical treatment. In addition, feeding problems are common in infants with CNPAS; therefore, supplemental feeding may be needed before and after the management of airway difficulties. ${ }^{3}$ In conclusion, this case report should remind general paediatricians and neonatologists to consider CNPAS as a possible cause of nasal obstruction in neonates.

\section{REFERENCES}

1. Brown $\mathbf{0 E}$, Myer CM 3rd, Manning SC. Congenital nasal pyriform aperture stenosis. Laryngoscope 1989;99:86-91.

2. Hui Y, Friedberg J, Crysdale WS. Congenital nasal pyriform aperture stenosis as a presenting feature of holoprosencephaly. Int J Pediatr Otorhinolaryngol 1995;31:263-74.

3. Sultan B, Lefton-Greif MA, Brown DJ, et al. Congenital nasal pyriform aperture stenosis: feeding evaluation and management. Int J Pediatr Otorhinolaryngol 2009;73:1080-4.

\section{Competing interests None.}

Patient consent Obtained.

This pdf has been created automatically from the final edited text and images.

Copyright 2010 BMJ Publishing Group. All rights reserved. For permission to reuse any of this content visit

http://group.bmj.com/group/rights-licensing/permissions.

BMJ Case Report Fellows may re-use this article for personal use and teaching without any further permission.

Please cite this article as follows (you will need to access the article online to obtain the date of publication)

Nakwan N, Songjamrat A, Phoophitphong R, Smathakanee C. Respiratory distress in neonate due to congenital nasal pyriform aperture stenosis. BMJ Case Reports 2010;10.1136/bcr.12.2009.2562, date of publication

Become a Fellow of BMJ Case Reports today and you can:

- Submit as many cases as you like

Enjoy fast sympathetic peer review and rapid publication of accepted articles

Access all the published articles

Re-use any of the published material for personal use and teaching without further permission

For information on Institutional Fellowships contact consortiasales@bmjgroup.com

Visit casereports.bmj.com for more articles like this and to become a Fellow 